\title{
The Influence of CSR, the Size of the Board of Commissioners and Leverage on Profitability of Manufacturing Companies Listed in BEI
}

\author{
Thomas Sumarsan Goh ${ }^{1}$, Henry $^{2}$, Erika $^{3}$ \\ ${ }^{1,3}$ Universitas Methodist Indonesia \\ ${ }^{2}$ Universitas Sumatera Utara, Indonesia \\ gohtho@gmail.com, henryciang451@gmail.com,iyoori.seol@gmail.com
}

\begin{abstract}
This research aims to know the impact of CSR, number of commissioners committee and leverage on profitability at manufacturing companies at Indonesian Stock Exchange. This study is quantitative descriptive. The data collection is from taking manufacturing companies' financial statements that are listed at Indonesian Stock Exchange, according to the number of samples, selecting from purposive sampling. Data analysis method is multiple regression method at 5\% of significant. The result of the study is the coefficient determination is $20.6 \%$, means that the impact of independent variables is $20.6 \%$, and the remaining is affected by other variables. The result of the study shows that leverage has impact on ROA, partially, and CSR and number of commissioner have no impact on ROA; however, simultaneously, CSR, number of commisioners and leverage has impacted significantly on $R O A$
\end{abstract}

Keywords

corporate social responsibility, number of commissioners, leverage; profitability

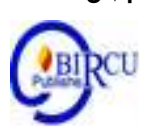

\section{Introduction}

Every company has one goal: to make a profit and improve a good image in society by paying attention to social responsibility. Companies can also be considered by the community as not paying attention to social aspects properly if they do not feel the negative impact of the operation of a company. This will be a problem for the company in building a good image for the community.

Corporate Social Responsibility (CSR) or corporate social responsibility is an effort made by companies to show their social responsibility as a form of ethics in building longterm performance (Muliyani, 2018). Manufacturing companies are selected by researchers to be objects in sample selection because the implementation of CSR in manufacturing companies has existed since the beginning of the company. And also, because manufacturing companies have more influence or impact on the surrounding environment, what occurs from the activities carried out by the company fulfills all aspects of the theme of CSR disclosure. Manufacturing companies are also trusted to get better trust from the public because they are vulnerable to political influence and criticism of the company's social activities, so it can be assumed that manufacturing companies can provide a wider disclosure of corporate social responsibility for non-manufacturing companies.

The development of social responsibility disclosure related to the increasingly severe environmental damage that has occurred in Indonesia and around the world can be seen from air pollution and factory waste, global warming, deforestation/burning of forests, poor quality and product safety, excessive exploitation of natural resources, abuse 
investment and so on (Wati, 2018). So, the company will be guaranteed if the company's orientation shifts from the starting point only on the measurement of economic performance. Now it must start on the balance of the environment and society by paying attention to social impacts (Hadi, 2011).

In the company, there are independent commissioners and members of the commissioner committee, which makes the company run more transparently. The committee is usually called an audit committee, with an independent commissioner as the committee's chairman. With the presence of independent commissioners, it is hoped that the company will be more open and transparent (Yurdila, Mukhzarudfa, \& Wiralestari, 2019).

The impact of corporate social activities varies depending on the type or characteristics of the company. The operating characteristics of the company that produces high social impacts will also require higher social responsibility. Therefore, this study uses company characteristics, namely profitability and leverage, as a reference.

The higher the leverage, the more likely the company will experience violations of debt contracts. Therefore, managers will try to report higher present profits than future profits (Susilowati, 2018; Susilowati, Wafirotin, \& Hartono, 2018). So, leverage provides an overview of the capital structure owned by a company so that it can be seen in advance the risk level of the company's debt uncollectibility. Companies that have high leverage ratios will disclose less CSR to report higher current earnings.

A company with a high profitability level will make wider disclosures to convince external parties that the company is in strong competition and the company's performance is good at that time. According to previous research conducted by Sitepu (2009) and Indriani (2011), profitability has a significant effect on social responsibility disclosure, while according to Adikara (2011), it does not affect social responsibility disclosure.

\section{Review of Literatures}

\subsection{Corporate Social Responsibility}

According to Amirullah (2015) corporate social responsibility or Corporate Social Responsibility (CSR) is a company's awareness of the external environment of the company carried out in order to guard the environment, the norm of the society, the development of participation, as well as various forms of social responsibility other. According to Amirullah (2015) there are several reasons why a company decides to implement Corporate Social Responsibility as part of its business activities, namely: the morality, the purification of its own interests, the theory of investment and maintain autonomy. According to Saleh et al (2019) in general, CSR (corporate social responsibility) or corporate social responsibility is defined as a business operation that is committed not only to increase company profits financially, but for regional socioeconomic development in a holistic, institutionalized and sustainable manner.

\subsection{The Benefits of Corporate Social Responsibility (CSR)}

According to Amirullah (2015) the benefits of corporate social responsibility as follows: corporate social responsibility will inevitably lead to a positive image of the company in the eyes of society and the government, the interests of society accommodated, public relations with the company will become more closely in a situation of win-win solution, danpemerintah feel to have colleagues in the social mission of the government in terms of social responsibility. 


\subsection{The Basis of the Legal Obligations of Corporate Social Responsibility (CSR)}

The obligations of the company in carrying out CSR are in Government Regulation No. 47 year 2012 about Social and Environmental Responsibility of Limited Liability, the Law No. 25 years of 2007 and Law No. 40 year 2007. In article 15 of the letters (b) of Law No. 25 year 2007 it is written that every investment is obliged to carry out the responsibility of the company. In Article 74 of Law No.. 40 year 2007 it is written that the company run a business related to natural resources is required to carry out social and environmental responsibility, a responsibility that should be taken into account as expenses of the company, the implementation of which is carried out with attention to the propriety and reasonableness, and if the company does not carry out such obligations will be subject to sanctions in accordance with the provisions of the applicable legislation.

\subsection{The Disclosure of Corporate Social Responsibility (CSR)}

The purpose of the disclosure of social responsibility is as a form of concern for the company both to shareholders and to the stakeholders (Sunaryo \& Mahfud, 2016). There is a goal of CSR disclosure in the annual report of the company (Tamba, 2011) is to improve and maintain the image of a company, usually implicitly, the assumption that the behavior of the fundamental company is better, freeing the accountability of the organization on the basis of the assumption of the social contract between the organization and the community, and as an extension of the traditional financial reporting and its purpose is to provide information to investors.

According to Andayani (2013), the level of CSR disclosure in the annual reports of the company are stated in the Corporate Social Responsibility Index (CSRI) will be assessed by comparing the amount of disclosure by the company as required by the GRI (Global Reporting Initiative). Tags-tags that are contained in the disclosure of CSR is the environment, energy, health and labor safety, product and eterlibatan community.As for the formula of the calculation of the Index Area of corporate social responsibility Disclosure (CSRI) as follows:

\section{$\operatorname{CSRI}_{j}=\frac{\mathrm{Ix}}{n}$}

Description:

CSRIj = Corporate Social Responsibility Index j.

$\Sigma x i j=$ the Number of items disclosed by the company $\mathrm{j}$.

$\mathrm{N} \quad=$ the Number of overall items, $\mathrm{n}=78$.

Hadi (2011) stated that there are three (3) basic principles of social responsibility (social responsibility) namely: sustainability, accountability, and transparency.

\subsection{Company Characteristics That Affect the CSR Disclosure}

Each company entity has different characteristics between each other. According to Lang and Lundholm in Anggraini (2006) "the characteristics of the company include, among others, capital structure, shareholders, profitability, leverage, company size, the size of the board of commissioners, ownership structure, corporate sector, the status of the company, and others". In this study the characteristics of the company that affect the disclosure of social responsibility is set in the size of the board of commissioners, profitability, and leverage. 


\subsection{Size of the Board of Commissioners}

According to Regulation No. 33/POJK.04/2014,the board of commissioners is the organ of the issuer or public company in charge of supervision in general and/or specifically in accordance with the articles of association as well as give advice to the board of directors. The board of commissioners at least consist of 2 members of the board of commissioners and 1 of whom was appointed a commissioner or president of the commissioners.

The board of commissioners in charge of supervising and responsible for the supervision of the top management policy, either of a public company, and give advice to the board of directors. The board of commissioners are required to conduct an evaluation of the performance of the committee in helping to carry out the duties and responsibilities of each financial year-end. The board of commissioners authorized in suspend a member of the board of directors to give a reason. The board of commissioners is obliged to convene the annual general meeting and other general meeting of shareholders in accordance with the authority at least once in 2 months.

The greater the number of members of the board of commissioners, the easier it is to control and monitoringdan things done will be more effective.

In order to be appointed into the board of commissioners, it shall meet the following requirements: have a moral and good integrity, abiding in the law, never to be members of the board of directors and/or members of the board of commissioners declared guilty in the cause of a company is declared bankrupt, never convicted of committing a criminal act that is detrimental to the country's financial and/or related to the financial sector, in the 5 years prior to appointment and during his tenure has never been declared bankrupt, have a commitment to comply with laws and regulations, and have the knowledge and/or expertise in the field required by the issuer or public company.

\subsection{Profitability}

According to Harahap (2013) profitability is described from the ability of the company to make a profit through all the abilities and resources there are activities such as sales, cash, capital, number of employees, number of branches, and so forth.According to Hery (2016) profitability is the ratio used in measuring the company's ability to generate profits from the normal activity of the business.

Profitability that is used to measure the ability of the company in generating income, namely ROA, ROE, GPM, OPM and NPM.In this study, which used radalah asio profitability, where the return on total assets or Return on Assets (ROA), because ROA is one of the west profabilitas that is able to measure the ability of a company in generating profits from assets that were used. In addition, the ROA was chosen as west as it can be used to measure the efficiency of the actions undertaken by the company.The formula used to calculate the return on assets that is:

\section{ROA $=\underline{\text { Net Profit After Tax }} \times 100 \%$ Total Assets}

\subsection{Leverage}

According to Harahap (2013) leverage is a ratio that describes the relationship between debt to equity of companies, this ratio can be seen the extent to which a company is financed by debt or outside parties with the ability of the company which is described by the capital. According to Brigham and Houston (2010), how far the company in the use of debt (financial leverage) will have 3 important implications, namely: to obtain funds 
through debt, the shareholders can maintain their control over the company while limiting the investment that they provide, the lender will look at equity, or funds obtained its own, as a limitation of security, so the higher the proportion of the amount of capital that is given to shareholders, then the smaller the risk faced by the lender, and if the company is getting the results of both funded and the results of the loan is greater than the interest paid, then the decision of the capital owners will be enlarged or mention it.

\subsection{Type of Leverage Ratio}

Yoehana (2013), stated the company with the leverage ratio higher will be trying to convey is a lot of information as an instrument to reduce monitoring costs for investors. The size of leverage in a company can affect the size of the tax paid by the company. This is because the interest costs of the debt can be deducted in calculating the tax so that the tax burden becomes smaller. As for the type of leverage ratio is the Debt to Assets Ratio (DAR), Debt to Equity Ratio (DER), Long Tern Debt to Equity Ratio (LTDtER) and Times Interest Earned (TIE). In this study, which is used to measure the level of leverage is the DER (Debt to equity ratio). Debt to Equity Ratio (DER), is a ratio used to assess the debt with equity. The formula used in calculating this ratio is as follows:

\section{DER $=$ Total Debt $\quad x 100 \%$ \\ Total Ekuitas}

\subsection{Conceptual Framework}

From a review of the literature that has been described above, it can be seen related variables in this study can be formulated through a framework of thought is as follows:

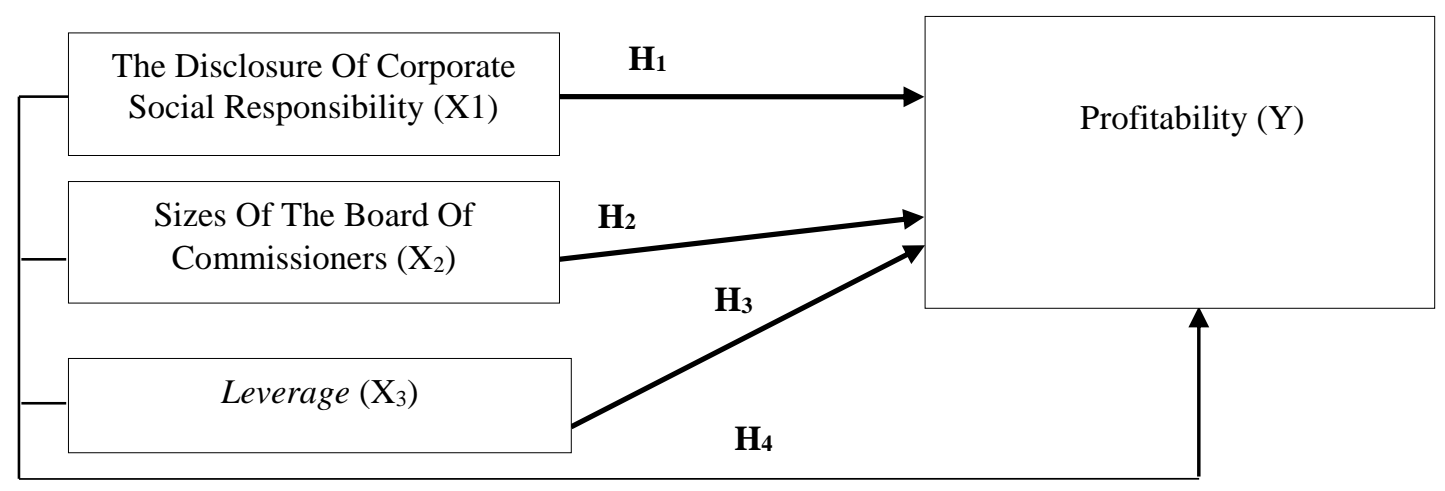

Figure 1. Conceptual Framework

Source: Data Processed the Author (2021)

\subsection{Hypothesis}

A hypothesis is a conclusion in a while are taken to answer the issues that have been proposed in the study. Based on a review of the theory and the framework above, it can be proposed in this study is as follows:

H1 : CSR significant effect on the ROA

$\mathrm{H} 2$ : the Size of the board of commissioners significant effect on the ROA

H3 : DER significant effect on the ROA

H4 : CSR, Size By DER, have a significant effect simultaneously on the ROA. 


\section{Research Methods}

This study obtained from the data of manufacturing companies listed in Indonesia stock Exchange (BEI), which uses data obtained indirectly through the medium of the internet with a website www.idx.co.id. The dependent variable is the variable being due to the presence of the independent variables (Sugiyono, 2012). The dependent variable that will be used in this research are profitability. ROA is the ability of a company in generating profits with the use of the assets of the company. The formula ROA can be formulated as follows:

\section{ROA $=\underline{\text { Net Profit After Tax }} \times 100 \%$ \\ Total Assets}

The independent variable is the variable that affects the dependent variable onset (Sugiyono, 2012). The independent variables used in this study is the Disclosure of Corporate Social Responsibility (CSR). The activities of Corporate Social Responsibility (CSR) is the commitment of the company voluntarily to participate in the welfare of the community. Research is a list of corporate social responsibility disclosure. The level of CSR disclosure in the annual reports of the company are stated in the Corporate Social Responsibility Index (CSRI) that will be assessed by comparing the number of disclosures made by companies with that implied by the GRI (Global Reporting Initiative), which amounted to 78 items the disclosure of Corporate Social Responsibility that includes themes of: economic, environment, labour practices, human rights, society and product responsibility (Andayani, 2013). The calculation formula of The Area of corporate social responsibility Disclosure (CSRI):

Description:

$$
\operatorname{CSRI}{ }_{j}=\frac{\sum x_{i j}}{n}
$$

CSRIj = Corporate Social Responsibility Index j.

$\Sigma x i j=$ the Number of items disclosed by the company $\mathrm{j}$.

$\mathrm{N} \quad=$ the number of overall items, $\mathrm{n}=78$.

Sizes of the board of commissioners is a member of the board of directors who have the influence to act independently solely for the benefit of the company (the national Committee of Governance Policy, 2004).Sizes of the board of commissioners judging from the number of board of commissioners in the internal of the company. Sizes of the board of commissioners can be formulated as follows:

\section{The Size of Board of Commissioner $=$ The Number of Members of the Board of Commissioners of the Company}

Leverage is the level of dependency of the company on debt to fund its operations, thus leverage also reflect the level of financial risk of the company. In this study, the ratio used to measure the level of leverage is the Debt To Equity Ratio (DER). The measurement can be formulated as follows:

$$
\text { DER }=\underset{\text { Total Ekuitas }}{\text { Total Debt }} \times 100 \%
$$


Table 1. Operational definition and Variable Research

\begin{tabular}{|c|c|c|c|}
\hline $\begin{array}{l}\text { Variable } \\
\text { Research }\end{array}$ & Operational Definition & Indicator & Scale \\
\hline $\begin{array}{l}\text { Disclosure } \\
\text { CSR (X1) }\end{array}$ & $\begin{array}{l}\text { The disclosure of social } \\
\text { information disclosed by } \\
\text { the company in its annual } \\
\text { report (Andayani, 2013). }\end{array}$ & $\operatorname{CSRI}=\frac{x_{i j}}{n}$ & Ratio \\
\hline $\begin{array}{l}\text { Sizes Of The } \\
\text { Board Of } \\
\text { Commissioners } \\
\text { (X2) }\end{array}$ & $\begin{array}{l}\text { The Organ of the issuer a } \\
\text { duty to conduct oversight } \\
\text { to the board of directors } \\
\text { (POJK } \\
\text { 33/POJK.04/2014). }\end{array}$ & $\begin{array}{l}\text { Sizes Of The Board Of } \\
\text { Commissioners } \\
\text { JumlahAnggota The Board Of } \\
\text { Commissioners Of The Company }\end{array}$ & Nominal \\
\hline $\begin{array}{l}\text { Leverage } \\
\left(\mathrm{X}_{3}\right)\end{array}$ & $\begin{array}{l}\text { Measure the extent to } \\
\text { which the company's assets } \\
\text { are financed with debt } \\
(\text { Henry, 2016). }\end{array}$ & DER $=\frac{\text { Total Debt }}{\text { Total Ekuitas }} \times 100 \%$ & Rasio \\
\hline $\begin{array}{l}\text { Profitability } \\
\text { (Y) }\end{array}$ & $\begin{array}{l}\text { Measure the ability of a } \\
\text { company in generating } \\
\text { profits from its business } \\
\text { activities (Hery, 2016). }\end{array}$ & ROA $=\frac{\text { Net Profit After Tax }}{\text { Total Assets }} \times 100 \%$ & Rasio \\
\hline
\end{tabular}

Source: Data Processed the Author (2021)

\section{Population and Sample}

Members of the population is called with the elements of the population (population element)(Sujarweni, 2014).The population used in this research is manufacturing companies listed in Indonesia stock Exchange during the period of 2014 to 2019. The method of analysis used is the analysis of regersi linear regression. Multiple linear regression analysis is the relationship is linear between two or more independent variables $(\mathrm{X} 1, \mathrm{X} 2, \ldots . \mathrm{Xn})$ with the dependent variable $(\mathrm{Y})$. Multiple linear regression equation as follows:

$$
\mathbf{Y}=\alpha+\beta_{1} \mathbf{X}_{1}+\beta_{2} \mathbf{X}_{2}+\beta_{3} \mathbf{X}_{3}+e
$$

Description:

$\begin{array}{ll}\mathrm{Y} & =\text { Profitability } \\ \alpha & =\text { Constant } \\ \boldsymbol{\beta}_{1}, \boldsymbol{\beta}_{2}, \boldsymbol{\beta}_{3} & =\text { regression Coefficient X1, X2, and X3 } \\ \mathrm{X} 1 & =\text { Corporate Social Responsibility } \\ \mathrm{X} 2 & =\text { Size of the board of commissioners } \\ \mathrm{X} 3 & =\text { Leverage } \\ \mathrm{e} & =\text { Error term (error estimators) }\end{array}$




\section{Discussion}

\subsection{The Influence of Corporate Social Responsibility (CSR) on the ROA}

From the test results it was stated that there was no significant influence of CSR on the ROA. Where can we see from the results of hypothesis testing showed significant value of $0.485>0.05$ and has a negative direction by the value of $t$ count $>t$ table ($0.701<1.98282$ ), so that $\mathrm{H} 0$ is accepted and $\mathrm{H} 2$ is rejected. That is, CSR is not significant effect on profitability. This result is at odds with research conducted by Rosdwianti, et al.(2016) showed that there is significant influence between the CSR with ROA.This result is also contrary to the study conducted by Candrayanthi and Saputra (2013) show that the CSR effect on ROA.

The implementation of CSR in creating a good image for the company and if the company has good image is not necessarily investors will be interested to invest the money. As for the factors which are viewed by some investors as the environment, the economy and so forth.

\subsection{The Influence of the Size of the Board of Commissioners on the ROA}

From the test results it was stated that there is no significant influence between the size of the board of commissioners of the ROA. Where can we see from the results of hypothesis testing showed significant value of $0.827>0.05$ and has a positive direction by the value of $\mathrm{t}$ count $>\mathrm{t}$ table $(0.219<1.98282)$, so that $\mathrm{H} 0$ is accepted and $\mathrm{H} 3$ is rejected.That is, the size of the board of commissioners no significant effect on profitability.The results of research conducted by Willar, Margantar and Tulung (2018) shows that there is no influence between the board of commissioners on the ROA.Members of the board of commissioners that a lot more can not improve the performance of the company higher. With the presence of the board of commissioners, the function of supervision of the operations of the company by the management, then the total membership of the board of commissioners should be able to provide supervision to the results of the operational process of the company.

\subsection{The Influence of DER on ROA}

From the test results it was stated that there is a significant influence between the der to ROA.Where can we see from the results of hypothesis testing showed a significant value of $0.000<0.05$ and has a negative direction by the value of $t$ count $<t$ table ($5.517<1.98282)$, so $\mathrm{H} 0$ is rejected and $\mathrm{H} 1$ is accepted. That is, DER significant effect on ROA. This result is at odds with research conducted by Sholikha, Susbiyani and F. A. Camellia (2019) show that there is no significant effect between leverage on ROA.

\subsection{The Effect of Leverage, CSR, and the Size of the Board of Commissioners of Profitability}

From the test results it was stated that there is significant influence between DER, CSR and the size of the board of commissioners of the ROA.Where can we see from the results of hypothesis testing showed a significant value of $0.000<0.05$ and have F count $>\mathrm{F}$ table $(10.282>2.69)$ so that $\mathrm{H} 0$ is rejected and $\mathrm{H} 4$ are accepted. That is, the DER, CSR and the size of the board of commissioners have a significant effect simultaneously on the ROA 


\section{Conclusion}

Based on the analysis and discussion, it is concluded that there is a partially significant influence between DER and ROA; there is no significant effect between CSR on ROA partially; there is no significant effect between the size of the board of commissioners on ROA partially; There is a simultaneous significant effect between DER, CSR, board size and ROA.

Based on the above conclusions, the suggestions can be described as follows:

1. The company is expected to be useful as a consideration in determining the company's optimization in increasing profit revenue through the leadership abilities of commissioners and directors in the company.

2. Investors are expected to be taken into consideration in deciding which investments to make by investors.

3. For further researchers, other variables can be used, such as PBV, EPS, etc., or in-depth research can be carried out so that the results obtained are more accurate.

\section{References}

Adikara, Y. Nata.2011. Pengaruh Karakteristik Perusahaan terhadap Pengungkapan Tanggung Jawab Sosial dalam Laporan Tahunan Perusahaan yang terdaftar di Bursa Efek Indonesia.Skripsi.Universitas Ekonomi Diponegoro. Semarang.

Andayani, A. N. 2013. "Pengaruh Karakteristik Social Responsibility terhadap Nilai Perusahaan dengan Profitabilitas sebagai Variabel Moderating.Sekolah Tinggi Ilmu Ekonomi Indonesia (STIESIA)".Jurnal Ilmu \& Riset Akuntansi, 2(5).

Anggraini, F. R. R. R. 2006. Pengungkapan Informasi Sosial dan Faktor-Faktor yang Mempengaruhi Pengungkapan Informasi Sosial dalam Laporan Keuangan Tahunan Studi Empiris pada Perusahaan-Perusahaan yang terdaftar pada Bursa Efek Jakarta.Simposium Nasional Akuntansi.

Amirullah.2015. Pengantar Manajemen Fungsi Proses Pengendalian. Jakarta: Mitra Wacana Media.

Brigham, E. F.,dan Joel, F. H. 2010. Dasar-Dasar Manajemen Keuangan. Edisi ke 3. Jakarta:Salemba Empat.

Candrayanthi, A. A. Alit., dan Saputra I. D. G. Dharma. 2013. "Pengaruh Pengungkapan Corporate Social Responsibility terhadap Kinerja Perusahaan (Studi Empiris pada Perusahaan Pertambangan di Bursa Efek Indonesia)". E-Jurnal Akuntansi Universitas Udayana, 4(1), 141-158.

Ghozali.2013. Analisis Multivariate dengan Program SPSS”. Edisi Ketujuh. Semarang: Badan Peneliti Diponegoro.

Hadi, Nor. 2011. Corporate Social Responsibility. Yogyakarta: Graha Ilmu.

Harahap, S. Syafri. 2013. Analisis Kritis Atas Laporan Keuangan. Jakarta: PT. Raja Grafindo Persada.

Hery. 2016. Analisis Laporan Keuangan : Integrated And Comprehensive Edition. Jakarta: PT. Grasindo.

Indriani, Mahtalia.2011. Analisis Pengaruh Karakteristik Perusahaan terhadap Pengungkapan Tanggung Jawab Sosial pada Perusahaan Perbankan dan Lembaga Keuangan yang terdaftar di Bursa Efek Indonesia.Skripsi. Universitas Sumatera Utara. Medan.

Muliyani, T. 2018. "Pengaruh Profitabilitas Leverage, Profil Perusahaan dan Ukuran Dewan Komisaris terhadap Pengungkapan CSR". Jurnal Ilmu dan Riset Akuntansi, 7(9), 1-21. 
Saleh, A., et al. (2019). Development of Banking CSR Model for Community Empowerment Slum Area in Medan City. Budapest International Research and Critics Institute-Journal (BIRCI-Journal). P. 39-50.

Sholikha, I., Susbiyani, Arik.,dan F. A. Kamelia, Ibna. 2019. "Pengaruh Coorporate Social Responsibility, Leverage dan Size terhadap Profitabilitas". International Journal of Social Science and Business, 3(3), 272-280.

Sitepu, Andre Christian. 2009. Faktor-Faktor yang Mempengaruhi Pengungkapan Informasi Sosial dalam Laporan Tahunan pada Perusahaan Manufaktur yang terdaftar di Bursa Efek Indonesia. Skripsi.Universitas Sumatra Utara. Medan.

Sugiyono. 2012. Metode Penelitian Kuantitatif dan R\&D. Bandung: Alfabeta.

Sujarweni, V. W. 2014. Metode Penelitian: Lengkap, Praktis, Dan Mudah Dipahami. Yogyakarta: Pustaka Baru Press.

Sunaryo, B. A dan Mahfud, H. M. K. 2016."Pengaruh Size, Profitabilitas, Leverage dan Umur terhadap Pengungkapan Tanggung Jawab Sosial Perusahaan (Studi Empiris Perusahaan Manufaktur yang Listing di BEI tahun 2010 - 2013)". Diponegoro Journal of Management, 5(2), 537-550.

Susilowati, F., Wafirotin, K. Z., dan Hartono, A. 2018."Pengaruh Ukuran Perusahaan, Profitabilitas, Leverage, Tipe Industri, dan Ukuran Dewan Komisaris terhadap Corporate Social Responsibility Disclosure (Studi Empiris pada Perusahaan Sektor Industri Barang Konsumsi yang terdaftar di Bursa Efek Indonesia periode 20132016)”. ISOQUANT: Jurnal Ekonomi, Manajemen dan Akuntansi, 2(2), 15-25. https://doi.org/10.24269/iso.v2i2.186

Susilowati, F. 2018. "Pengaruh Ukuran Perusahaan, Profitabilitas, Leverage, Tipe Industri, dan Ukuran Dewan Komisaris terhadap Corporate Social Responsibility Disclosure". Journal of Business Ethics, 14(3), 37-45.

Rosdwianti, M. K., A. R, Moch. D., dan Z. A. Zahroh. 2016. "Pengaruh Corporate Social Responsibility (CSR) terhadap Profitabilitas Perusahaan (Studi pada Sektor Industri Barang Konsumsi yang terdaftar di Bursa Efek Indonesia Periode 20132014)".Jurnal Administrasi Bisnis (JAB), 38(2), 16-22.

Tamba, E. G. H. 2011. Pengaruh Struktur Kepemilikan terhadap Pengungkapan Tanggung Jawab Sosial Perusahaan.Skripsi.Universitas Diponegoro. Semarang.

Wati, Lela N. 2018. "Faktor-Faktor yang Mempengaruhi Pengungkapan Corporate Social Responsibility dengan Dimensi Pengungkapan Lingkungan, Ekonomi dan Sosial”. Jurnal Ecodemica, 2(2), 240-252.

Wilar, F. F., Mangantar, M., dan Tulung, J. E. 2018."Pengaruh Corporate Governance terhadap Return On Asset (ROA) pada Lembaga Pembiayaan terdaftar di BEI tahun 2012-2016". Jurnal EMBA : Jurnal Riset Ekonomi, Manajemen, Bisnis dan Akuntansi, 6(4), 2698-2707.https://doi.org/10.35794/emba.V6i4.21051

Yoehana, Maretta. 2013. Analisis Pengaruh Corporate Social Responbility terhadap Agresivitas Pajak. Skripsi. Universitas Diponegoro. Semarang.

Yurdila J. M., Mukhzarudfa.,dan Wiralestari. 2019. "Pengaruh Profitabilitas, Ukuran Perusahaan, Dewan Komisaris, Leverage dan Pengungkapan Media terhadap Pengungkapan Corporate Social Responsibility (CSR) pada Perusahaan yang Go Public dan Listing di Bursa Efek Indonesia (BEI)". Jurnal Akuntansi \& Keuangan Unja, 4(4), 11-25. https://doi.org/10.22437/jaku.v4i4.8444

Peraturan Pemerintah No. 47 Tahun 2012 tentang Tanggung Jawab Sosial dan Lingkungan Perseroan Terbatas.

Undang-Undang Nomor 25 Tahun 2007 tentang Penanaman Modal.

Undang-Undang Nomor 40 Tahun 2007 tentang Perseroan Terbatas.

www.idx.co.id 